\title{
Phytopathology
}

\section{The Impact of "Coat Protein-Mediated Virus Resistance" in Applied Plant Pathology and Basic Research}

\author{
John A. Lindbo and Bryce W. Falk
}

First author: HM Clause, 28605 County Road 104, Davis, CA 95618; and second author: Department of Plant Pathology, University of California, Davis 95616.

Accepted for publication 17 February 2017

\begin{abstract}
Worldwide, plant viruses cause serious reductions in marketable crop yield and in some cases even plant death. In most cases, the most effective way to control virus diseases is through genetically controlled resistance. However, developing virus-resistant (VR) crops through traditional breeding can take many years, and in some cases is not even possible. Because of this, the demonstration of the first VR transgenic plants in 1985 generated much attention. This seminal report served as an inflection point for research in both basic and applied plant pathology, the results of which have dramatically changed both basic research and in a few cases, commercial crop production. The typical review article on this topic has focused on only basic or only applied research results stemming from this seminal discovery. This can make it difficult for the reader to appreciate the full impact of research on transgenic virus resistance, and the contributions from fundamental research that led to translational applications of this technology. In this review, we take a global view of this topic highlighting the significant changes to both basic and applied plant pathology research and commercial food production that have accumulated in the last 30 plus years. We present these milestones in the historical context of some of the scientific, economic, and environmental drivers for developing specific VR crops. The intent of this review is to provide a single document that adequately records the significant accomplishments of researchers in both basic and applied plant pathology research on this topic and how they relate to each other. We hope this review therefore serves as both an instructional tool for students new to the topic, as well as a source of conversation and discussion for how the technology of engineered virus resistance could be applied in the future.
\end{abstract}

Additional keywords: genetically engineered virus resistance, pathogen-derived resistance, RNAi.

Essentially all plants that humans grow for food and/or fiber can be affected by diseases caused by plant viruses (Hull 2014). It has also recently been shown that many presumed "healthy" plants also contain viruses (Muthukumar et al. 2009). Thus, viruses can be found wherever plants are grown. As pathogens, they cause significant agricultural losses in crops worldwide, in both subsistence farming and modern agricultural settings. New viruses are continually discovered, new virus strains continue to evolve and adapt to our efforts to control them, and viruses (or their vectors) continue to be introduced into new areas leading to emergence of new virus diseases (Anderson et al. 2004). These things make viral diseases problems in agriculture and even to plants in natural ecosystems (Malmstrom and Alexander 2016).

In terms of their composition and structure, plant viruses show incredible diversity. Viruses of different taxa show distinctly different molecular and genetic composition. The virions for different viruses come in many different shapes and sizes, and the type (single- or double-stranded RNA or DNA) and amount of genetic material varies

Corresponding author: J. A. Lindbo; E-mail address: john.lindbo@hmclause.com

(C) 2017 The American Phytopathological Society among different types of viruses (Hull 2014). But regardless of their makeup, all viruses are intracellular, obligate parasites that utilize the host plant translational machinery to express their own genetic material. This intimacy between virus and host is one of the factors making controlling virus diseases by chemical-based approaches so difficult. Other plant pathogens such as fungi, bacteria, and nematodes have biochemical pathways unique from their plant hosts. As a result, these pathogens can sometimes be controlled by chemicals that specifically target pathogen-specific biochemical pathways. By contrast, we do not have viricides that can be applied to the plant host and specifically interfere with the virus infection. In general, chemicals that affect the virus also affect the host cell. And because of the diversity of plant-infecting viruses, no single approach can be considered for universal virus disease control.

Over time humans have developed a variety of technical approaches and strategies to deal with the problem of plant virus diseases. Prior to the development of the transgenic plant era, strategies available to growers included good sanitation practices, breeding plant varieties for resistance, chemical control of insect vectors, and, occasionally, cross protection between viruses. The preferred and often the most effective strategy for virus control is a combination of sanitation and 
growing plants that are genetically virus-resistant (VR) (Kyle 1993). The amount of time and effort needed to develop a VR plant variety depends upon the genetics of virus resistance and the generation time of the host plant. Virus resistance genes can demonstrate recessive, additive, or dominant modes of inheritance (Whitham and Hajimorad 2016). In those cases where resistance is recessive or involves multiple genes, breeding effective resistance can be challenging. In addition, breeding host plants with long generation times (like trees for example) can be so difficult and time consuming that traditional breeding is not a realistic option. In addition, there are many virus-plant combinations for which effective resistance genes have not been identified. In the absence of effective genetic control options for insect transmitted viruses, growers often try to limit virus spread by chemical control of insect vectors. Some of the most important insect vectors of plant viruses include aphids, whiteflies, thrips, and leafhoppers (Whitfield et al. 2015), all of which can be difficult to control through chemicals. In addition to having negative impacts on the environment, managing plant viruses through chemical control of insects is often not effective. For example, many economically important plant viruses are spread by aphids in a noncirculative, nonpersistent manner. In this mode of transmission aphids can acquire and transmit viruses as they probe plants, before they begin active feeding (Whitfield et al. 2015). This probing activity can last only seconds. As a result, aphids can spread a stylet-borne virus in a field before an insecticide can kill them, making the chemical control strategy essentially noneffective.

Another occasionally used virus control strategy is cross protection. McKinney first demonstrated cross protection with Tobacco mosaic virus (TMV) (McKinney 1929). He observed that plants already infected with one strain of TMV were resistant to infection with a second, closely related TMV strain. Other researchers soon showed that the "cross protection" phenomenon worked with many different viruses of diverse virus taxa, and it was recognized that cross protection might have practical applications for virus disease control in agriculture. If a plant could be first inoculated with a mild strain of a virus, the plant might be resistant to "super-infection" later by more severe strains of this same virus. Despite that cross protection is not fully understood on a mechanistic level (Bergua et al. 2016; Folimonova 2013), it has been used in commercial agricultural settings. In some cases, cross protection proved to be very effective and give the desired disease control. The most widespread use of cross protection was probably to protect citrus plants from infection by severe forms of Citrus tristeza virus, but cross protection also has been used against the potyviruses Papaya ringspot virus (PRSV) and Zucchini yellow mosaic virus (ZYMV). For a review of cross protection, see Ziebell and Carr (2010).

In most cases, of all these options the most valuable and environmentally sound way of controlling virus diseases is to grow VR plants. The main limitation in this strategy is that effective naturally occurring virus resistance genes are often hard to find, difficult to manage in a breeding program and in some cases not available. At the dawn of the transgenic plant era, addressing the limited availability of effective plant virus resistance genes was a clear objective. The first example of genetically engineered virus resistance was TMV resistance in tobacco (Nicotiana tabacum) (Abel et al. 1986). Researchers hypothesized that they could develop resistance genes from plant virus sequences, perhaps duplicating the phenomenon of cross protection transgenically. After this initial success, there was a rush to apply this same strategy to viruses of many other taxa including many aphidvectored plant viruses that proved difficult to control with insecticides and were problematic pathogens. The results were remarkably successful and led both to commercially released VR plants and to many surprising basic research discoveries along the way.

With the first 30 years of research on genetically engineered virus resistance we have accumulated an incredible amount of insight into biology, developed more accurate and efficient strategies for engineering resistance, and have observed the economic and environmental benefits of using genetically engineered virus resistance in real-world agricultural settings. Our strategies and insights have improved to a point where it is now possible to effectively engineer resistance against essentially any virus. In some cases, resistance can be achieved when no other options are available. Why genetic engineering approaches are not more often used for sustainable, environmentally sound virus disease control is a complicated sociological and political scenario. We won't discuss that here. Here we will describe how genetically engineered virus resistance came about, how it works, show commercial examples of its success, and argue for its benefit not just to plant pathology, but to sustainable agriculture and feeding our planet.

\section{COAT PROTEIN-MEDIATED RESISTANCE: THE FIRST EXAMPLE OF PATHOGEN-DERIVED RESISTANCE FOR PLANTS}

In 1985, Sanford and Johnston published the concept of parasite (or pathogen)-derived resistance (PDR) (Sanford and Johnston 1985). They suggested that the newly emerging genetic engineering technologies could be used to confer resistance by "cloning the appropriate parasite gene, modifying its expression if necessary, and transforming it into the host genome" (Sanford and Johnston 1985). Then, when the corresponding gene product is expressed in the host, this could yield "faulty signals" which would disrupt the normal replication and infection cycle of the parasite. This disruption could then result in a resistance phenotype. This concept was especially appealing as a resistance strategy for plant viruses for several reasons. First, all plant viruses, no matter their taxonomic group, are all obligate intracellular parasites so this approach could be applied to any virus. Second, most plant viruses have fewer than $\sim 10$ genes, so this strategy could be tested by experimenting with only a few genes. And finally, the strategy could be applied without detailed knowledge of all the functions of a virus gene or protein. It was simply hypothesized that inappropriate, unregulated expression of selected virus genes/proteins by the host plant would somehow lead to virus dysfunction and therefore resistance. The simple, logical tenants of this theory made it very appealing.

In 1986, Abel and colleagues reported the first example of genetically engineered virus resistance. They demonstrated resistance to TMV in transgenic tobacco plants engineered to express the TMV coat protein (CP) gene (Abel et al. 1986). At that time, the assumption was that virusencoded proteins such as the $\mathrm{CP}$ were the likely determinants for the phenomenon of cross protection, which was being used in some agricultural settings to control virus diseases. To test this hypothesis, Beachy and colleagues engineered plants to express the TMV CP (Abel et al. 1986). They then selected for transformed tobacco plants that accumulated TMV CP and challenged several transgenic $\mathrm{CP}$-expressing $(\mathrm{CP}+)$ lines with various quantities of TMV. They found that the $\mathrm{CP}+$ plants reacted differently from the nontransgenic tobacco plants. $\mathrm{CP}+$ plants showed greater resistance to TMV infection. This resistance was demonstrated in two ways: (i) some of the $\mathrm{CP}+$ plants showed a lower percentage of TMV-infected plants than did the nontransgenic controls; and (ii) those that became infected developed symptoms later after inoculation than did the nontransgenic plants. By increasing the inoculum level, this delay in appearance of symptoms was reduced. None of the plants were immune to TMV challenge.

In subsequent experiments, it was determined that $\mathrm{CP}+$ plants (or protoplasts) were resistant to challenge by TMV virions but showed little resistance to challenge with TMV RNA or virus particles which were partially uncoated (Nelson et al. 1987; Register and Beachy 1988). The authors interpreted this result as indicating that expression of CP from the transgene was inhibiting an early step in virus infection, such as uncoating of the virion RNA (Osbourn et al. 1989). Other experiments involving plant grafting suggested that virus movement was also being impacted (Osbourn et al. 1989; Wisniewski et al. 1990). The overall result was that the exact 
mechanism(s) of virus resistance in TMV CP+ plants was not clear. It seemed that multiple stages of the TMV infection cycle were impacted. And it seemed only reasonable that the transgene expressed CP was responsible for the resistance (Nejidat and Beachy 1989). The logical extension of this observation was that virus resistance was likely to be stronger in transgenic plants that had higher $\mathrm{CP}$ expression levels. Initially, Beachy proposed naming the phenomenon "genetically engineered cross protection." However, since neither the mechanisms of cross protection nor the mechanism of resistance in $\mathrm{CP}+$ plants was clear the phenomenon was termed "coat protein-mediated resistance" (CPMR) (Beachy 1999).

\section{EARLY RESEARCH IN THE FIELD OF PDR}

The initial demonstration of CPMR created intense scientific interest. Within 3 years, the CPMR approach was tested on viruses of at least five other taxa (Beachy et al. 1990). The degrees of resistance observed were generally a delay in the appearance of symptoms and/ or a reduction in symptom severity. At the time, it was expected that $\mathrm{CP}$ expression levels would be positively correlated with the degree of resistance, but in many cases the data did not show a good correlation with this hypothesis. For example, multiple transgenic plant lines expressing the Cucumber mosaic virus (CMV) $\mathrm{CP}$ from a transgene were generated. When challenged with CMV, different plant lines expressing what appeared to be essentially equivalent amounts of the CMV CP showed different degrees of resistance (Cuozzo et al. 1988; Quemada et al. 1991). Researchers testing the theory of CPMR against viruses of other taxonomic groups made similar observations. Some potato (Solanum tuberosum) plants engineered to express the Potato virus $Y$ (PVY) CP from a transgene were found to be resistant to PVY challenge. However, the plant lines with highest resistance to PVY were not the highest $\mathrm{CP}+$ expressing lines (Lawson et al. 1990). Similarly, transgenic potatoes expressing the Potato leaf roll virus (PLRV) CP were resistant to PLRV, but expression of transgene-encoded CP could barely be detected (Kawchuk et al. 1990). It seemed that there were likely multiple mechanisms of resistance, and that the mechanism(s) of CPMR could differ from one plant virus system to another, and perhaps even from one transgenic plant to another. Multiple explanations were proposed, including tissue-specific expression of CP (Clark et al. 1990). Regardless of the mechanism(s), it was clear that the concept of PDR was effective for viruses of many different taxa and in many different plants. The opportunities were also clear.

The theory of PDR, of course, was not limited to just expression of $\mathrm{CP}$ genes as resistance genes. If transgenically expressed CP can confer resistance, what about other virus-encoded proteins? Several efforts were undertaken to address this question. In one of the first examples tobacco plants were engineered to express the TMV 54-kD protein, a putative protein component of the TMV RNA-dependent RNA polymerase (replicase) (Golemboski et al. 1990). High levels of virus resistance, in effect immunity, were achieved in transgenic plants or in single cells from these plants, but the transgenically expressed protein was not detectable. Soon other examples of "replicase-mediated resistance" followed for viruses of other taxa (Anderson et al. 1992). In considering all the examples of PDR in the first few years of this emerging field, the following concepts began to emerge: (i) PDR can be obtained through the use of multiple different genes; (ii) high levels of transgene expressed protein were not necessarily correlated with the degree of resistance; (iii) there were no doubt different mechanisms of resistance, depending upon the virus system, and the virus gene/protein being expressed by the transgenic plant; and (iv) degrees of resistance obtainable using PDR could range from a short delay in appearance of symptoms to virus immunity. Many groups were performing either basic or applied research on the topic. We first review the application of PDR to real-world plant pathology problems, focusing on those transgenic plants that were approved for commercial use. Then we discuss how basic research on PDR led to an improved understanding of the mechanisms behind PDR and how to improve its efficiency. Figure 1 presents a timeline of some of the key developments in both applied and basic research that grew out of the first demonstration of genetically engineered virus resistance.

\section{PART I. APPLIED RESEARCH ON PDR: ADDRESSING REAL-WORLD PROBLEMS}

The early successes of PDR using CP or replicase sequences immediately caught the interest of plant breeding companies. Breeding for plant virus resistance is a major objective for commercial vegetable and fruit breeding programs because of the significant crop losses virus infections can cause. If available, genetic resistance offers environmentally sound and effective means to manage plant diseases, making it an appealing trait to growers. However, depending upon the crop and the growing area, the virus resistance needs vary.

A real challenge for plant breeding companies was to find existing sources of resistance and cross these genes into elite inbred plant lines. This is a time consuming and resource intensive effort. Much time and effort is first spent screening plant accessions (including wild plant species) for virus resistance. Then once identified, the genetic basis of resistance must be determined (dominant, recessive, single, or multigenic, etc.) and then the resistance gene(s) must be crossed into commercially relevant germplasm. Finally, multiple generations of pathogen challenge and selecting and self-fertilization of plants must be performed to generate a high quality inbred line that breeds true for the virus resistance trait. This process alone can take many years when dealing with a simple single dominant gene mode of inheritance. If resistance is multigenic or recessive in nature, this process is particularly difficult to manage and takes many more plant generations, and larger plant population sizes. Once a VR inbred plant line is generated it may be crossed to make hybrid varieties or may be commercially advanced as an inbred line. Either way, before being sold commercially new plant varieties typically undergo multiple years of additional trialing and testing in multiple locations versus commercially available varieties. Only if a new variety is demonstrated to reliably perform "better" than those already available would it be sold commercially. This same general approach is still followed today.

When examples of CPMR began appearing in the scientific literature plant breeders were struggling to develop virus resistance in several different important fruit and vegetable crops. In many cases, effective virus resistance genes were not even identified. Or, if known, the sources of virus resistance were in distantly related species with a large number of undesirable traits, resistance was often multigenic in nature and difficult to work with and often not very effective. The demonstration that it was possible to construct a virus resistance gene from a virus' own genome was a simple, straightforward and fairly rapid solution to the problem of breeding for virus resistance. As a result, a number of groups began applying the CPMR strategy toward the viruses that were most problematic in important food crops. Many excellent experiments were also performed on nonfood crops, though they will not be discussed here. The fact that the exact mechanism(s) of engineered virus resistance was not clear at the time was not a hindrance. Plant breeders had been using natural virus resistance genes for decades without any knowledge of the mechanisms of resistance. The main problem had been identifying sources of high levels of resistance that were easy to work with from a genetic standpoint. There was a strong need for new effective sources of virus resistance for many important food crops and remarkably rapid progress was made by applying the concept of CPMR/PDR. Eventually food crops engineered for resistance to aphid-transmitted potyviruses, luteoviruses, and cucumoviruses were developed, proven to be very effective, and some were commercially released. These examples, as well as other examples of engineered VR plants approved for commercial release will be discussed briefly below. 
Genetically engineered virus resistance in squash. Some of the most significant virus diseases of squash (Cucurbita pepo) in the United States in the early 1990s were caused by CMV and potyviruses such as ZYMV and Watermelon mosaic virus (WMV) (Kyle 1993). Some sources of resistance to these viruses had been identified in multiple different cucurbit species; however, the resistance seemed to be multigenic in nature and not always highly effective. The available resistance genes were not easy for plant breeders to work with. Both potyviruses and CMV are transmitted by aphids so rapidly that controlling spread of these viruses with insecticides was not effective (though still often attempted). Genetically based resistance was the most desirable and effective way of limiting losses due to these viruses and discouraging growers from unnecessarily spraying insecticides. As of the early 1990s, conventional breeding approaches had failed to deliver highly effective multivirus resistant squash (referenced in Arce-Ochoa et al. [1995]). There was a desperate need for multivirus resistance in squash.

Based on the results of the Beachy lab and others, Tricoli et al. (1995) applied the CPMR strategy to develop multivirus resistant summer squash lines. Expression cassettes consisting of a single virus $\mathrm{CP}$ gene sequence joined to a plant-functional promoter were constructed. Recombinant DNA molecules of either two or three different expression cassettes were assembled and transferred into squash cells by Agrobacterium tumefaciens-mediated transformation. Transgenic plants expressing both the ZYMV and WMV CP genes were resistant to these two viruses. Transgenic plants expressing the CP genes of ZYMV, WMV, and CMV showed resistance to all three viruses. Multivirus resistant transgenic squash plants were deregulated in the United States in 1994 and 1996 (Fig. 1), and were the first VR transgenic plants commercially sold.

The ability to construct a single dominant genetic locus that could confer effective resistance to multiple viruses was a remarkable achievement and a tremendous practical advantage for plant breeding programs. This made it easy to move multivirus resistance as a single dominant locus into new squash inbreds or hybrids by traditional breeding methods. The field performance of these squash was very impressive. One field trial reported that engineered VR squash resistant to all three viruses had a remarkable 50-fold

\section{FIGURE 1}

Timelines of selected research milestones in applied and basic research on genetically engineered virus resistance. A, Selected basic research milestones. The first demonstration of engineered virus resistance (1986) was an example of coat proteinmediated resistance (CPMR) in transgenic tobacco plants expressing the Tobacco mosaic virus (TMV) coat protein (CP) gene.

Selected key observations since then include, demonstration that genes other than virus $\mathrm{CP}$ can be used as synthetic resistance genes (1990); discovery that resistance can be RNA-mediated (1992),

proposed model for RNA-mediated resistance (1993); discovery that dsRNAs are potent triggers of RNA-mediated silencing (1998); discovery of small RNAs complementary to a transgene in plants undergoing transgene silencing (1999); construction of an artificial miRNA gene that can confer virus resistance (2006). B, Applied research milestones. Year of deregulation of virus-resistant (VR) plants in various countries: United States, blue boxes; China, red boxes; and Brazil, brown boxes. Green boxes identify time when VR crops were known to be commercially sold. Commercial sales data from China are not available for VR pepper and tomato. For each crop, the virus(es) for which resistance was engineered is listed. Abbreviations: CMV, Cucumber mosaic virus; PPV, Plum pox virus; PRSV, Papaya ringspot virus; PLRV, Potato leaf roll virus; PVY, Potato virus Y; ZYMV, Zucchini yellow mosaic virus; and WMV, Watermelon mosaic virus.

References indicated by superscript numbers: 1 (Abel et al. 1986), 2 (Golemboski et al. 1990), 3 (Lindbo and Dougherty 1992a), 4 (Lindbo et al. 1993), 5 (Waterhouse et al. 1998), 6 (Hamilton and Baulcombe 1999), and 7 (Niu et al. 2006).

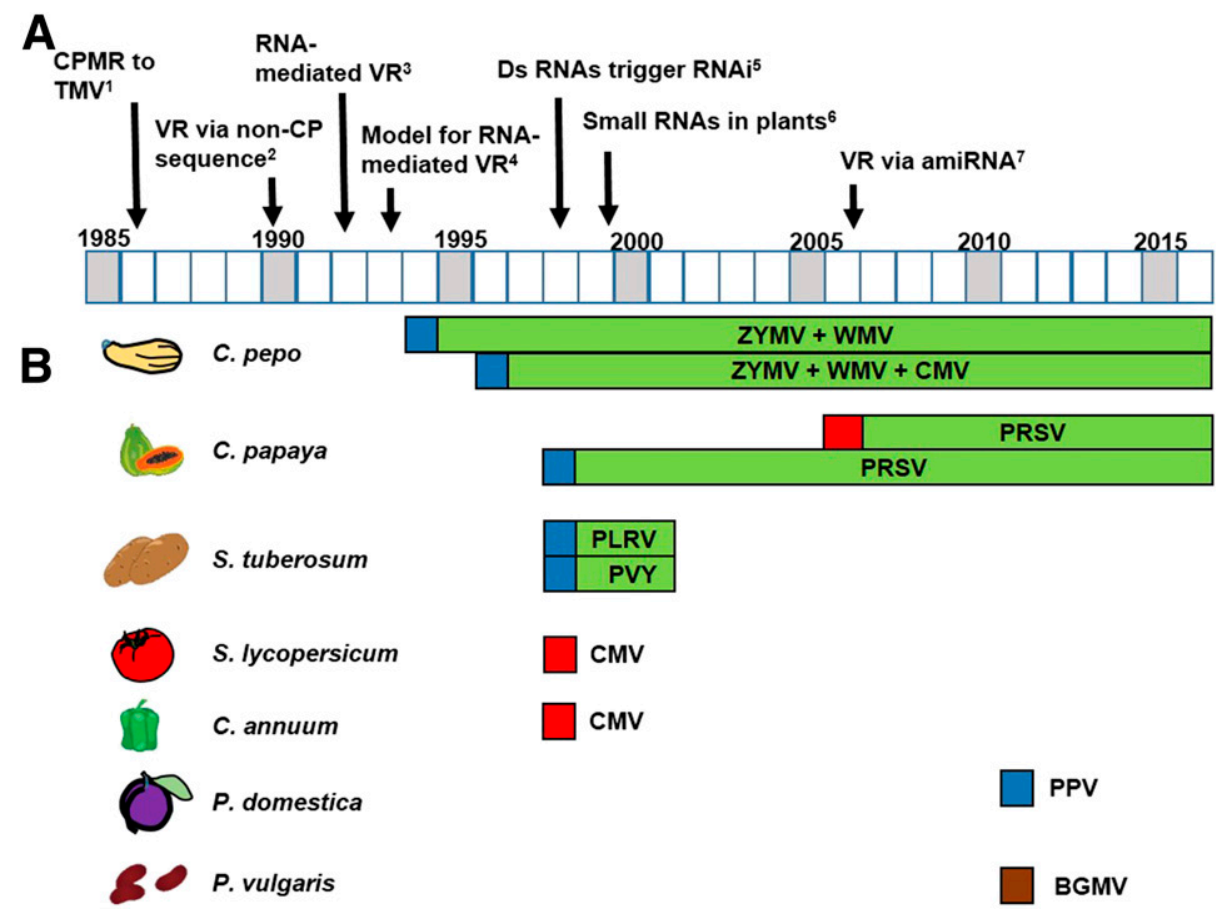


increase in marketable yield over susceptible control lines (Fuchs et al. 1998). Even after more than two decades of continuous use, engineered VR transgenic squash is still performing well and commercially grown in the United States. In 2006, these resistance genes were in about $12 \%$ of all U.S. squash production and were still providing effective protection against ZYMV, WMV, and CMV infection. Furthermore, a 2007 study estimated the benefit of this technology to growers at \$24 million (Johnson et al. 2007). Engineered VR squash continue to be grown in the United States today (2017).

Genetically engineered virus resistance in potato. Diseases caused by the aphid-transmitted viruses Potato virus $Y$ (PVY, a member of the genus Potyvirus) and Potato leafroll virus (PLRV, a member of the genus Polerovirus) were major problems in potato in the 1990s. Could transgenic virus resistance be developed for these important viruses in this important U.S. crop? Transgenic potatoes expressing the PVY CP gene were found to be highly resistant to PVY (Kaniewski et al. 1990). Curiously, the most PVY resistant lines did not accumulate the highest levels of CP so the mechanism of resistance was not clear. Regardless, the lines proved highly resistant to PVY even under field conditions. In other experiments, multiple transgenic potato lines expressing the PLRV CP gene were generated and tested (Kawchuk et al. 1990). While some lines were resistant in greenhouse studies, none of these lines showed PLRV resistance under field conditions (Kaniewski and Thomas 2004). In response to this negative result, transgenic potatoes expressing the PLRV replicase gene were generated. Knowing that the correlation between transgene expression levels and virus resistance was not good, transgenic plant lines were simply screened for resistance as soon as possible. After screening more than 1,000 transgenic potato lines in the field, approximately 300 were found to be PLRV resistant. The three best lines (in terms of yield, field resistance, and product quality, etc.) were eventually commercialized (Kaniewski and Thomas 2004).

After multiple years of field testing, PVY- or PLRV-resistant potatoes were deregulated and commercially grown in the Northwest region of the United States beginning in 1999. These transgenic potatoes had significant impact for growers and very positive impacts on the environment. Kaniewski and Thomas (2004) reported that by growing PLRV-resistant transgenic potatoes in the Columbia Basin or Idaho regions of the United States, farmers saved approximately $\$ 164$ or $\$ 141$ per acre, respectively. In addition, they estimated that if $80 \%$ of the Burbank potato acres in this region were planted with PLRV-resistant transgenic potatoes, pesticide applications could be reduced by over 1.8 million pounds of insecticide per year. Obviously these transgenic potatoes were very popular with growers, provided environmental benefits, and consumers received a higher quality product. Regardless of these benefits, activists began coordinating an antibiotechnology campaign against these potatoes in 1999. The campaign was highly successful. Although there were absolutely no data indicating that these potatoes were significantly different or less safe than nontransgenic potatoes, VR transgenic potatoes were not grown commercially in the United States after 2001 due to concerns of consumer acceptance of the potatoes (Kaniewski and Thomas 2004). As a result of these VR transgenic potatoes not being grown, it is likely that the 1.8 million pounds of insecticide that could have been eliminated continue to be applied to the crop and the environment.

Genetically engineered virus resistance in papaya. Arguably, the most successful example of an engineered VR crop is papaya (Carica papaya). Papaya ringspot virus (PRSV, a member of the genus Potyvirus) infection is the cause of the most destructive disease of papaya and is a major disease problem worldwide. PRSV infection of papaya causes severely reduced fruit production, leads to symptomatic, unsaleable fruit, and ultimately kills the papaya tree. PRSV, like other potyviruses, is aphid transmitted in a nonpersistent noncirculative manner making it very difficult to control. Unfortunately, there were no sources of effective virus resistance for breeding programs to deploy. A number of recent and excellent reviews cover many different aspects of the VR transgenic papaya story in more detail (Fitch 2016; Fuchs and Gonsalves 2007; Gonsalves 2015; Kumari et al. 2015; Tripathi et al. 2007).

In the late 1980s, Gonsalves and coworkers began working to apply the "coat protein-mediated resistance" approach to generate PRSVresistant papaya. After years of effort they succeeded in producing a transgenic papaya expressing the PRSV CP gene (Fitch et al. 1993; Fitch et al. 1992). Testing for PRSV resistance under field conditions began in the Oahu region of Hawaii in 1992. Within months, the transgenic papaya field test showed great success. In the first field trial, all of the control plants became infected with PRSV, but the transgenic papaya were completely protected (Lius et al. 1997).

Also in 1992, PRSV infection appeared in Puna, the major papaya production region in Hawaii. The virus spread rapidly within this region and caused significant reductions in marketable yield. From 1992 to 1998 papaya production levels in Puna were nearly halved (VIB 2014). Field trial results with VR engineered papaya showed excellent results. In one trial the transgenic papaya yielded 125,000 pounds per acre per year. In contrast, the nontransgenic fields produced only 5,000 pounds per acre per year (Gonsalves et al. 2004). Figure 2 shows the dramatic difference between virus susceptible and transgenic VR papaya under field conditions in Hawaii. In 1997, after many years of testing, transgenic papaya was deregulated in the United States (USDA-APHIS 2016). Transgenic papaya plants were first commercially available in 1998. In less than 4 years VR papaya enabled Hawaiian papaya production to return to pre-PRSV levels. These transgenic papaya lines have provided millions of dollars of value to Hawaiian papaya growers. In 2009 the Hawaiian papaya export market was valued at over $\$ 14$ million, and over $75 \%$ of the Hawaiian papaya grown was engineered VR (VIB 2014). The VR papaya has also allowed the market to grow. In 2012, the Hawaiian papaya export market was valued at over \$23 million (VIB 2014).

The extensive cultivation of VR papaya in Hawaii had other positive consequences. The high percentage of VR papaya plants grown reduced virus pressure enough to allow nongenetically engineered papaya to be successfully grown. Buffer zones of transgenic papaya could protect nontransgenic papaya within the zones (Fitch 2016). Thus, large scale cultivation of genetically engineered papaya also made it possible to grow nongenetically engineered papaya.

Transgenic papaya has also been valuable to growers in other parts of the world. In 2006, transgenic PRSV-resistant papaya expressing the PRSV CP gene from a transgene was deregulated in China. An estimated 3,500 ha of genetically modified papaya were grown in China in 2007. By 2012 this had risen to 6,275 ha, representing more than $60 \%$ of the land area used for papaya in China (VIB 2014). As of 2017, engineered VR papaya is still a major percentage of papaya grown in both Hawaii or China.

Genetically engineered virus resistance in plum. The most serious viral disease for the stone fruit industry is Sharka disease, caused by Plum pox virus (PPV, a member of the genus Potyvirus) infection. First discovered in Bulgaria in Eastern Europe in the early 1900s, it has since spread worldwide (Garcia et al. 2014). Sharka disease is particularly widespread in Europe where an estimated 100 million stone fruit trees are infected. The disease causes severe mottling and fruit deformation significantly reducing the marketable yield of the tree. Rogueing of infected trees to remove sources of inoculum is part of an effective, though very expensive, disease control strategy. Between 1989 and 2006 more than 2.3 million trees in Spain were removed in attempts to control PPV. The total cost of this was estimated to exceed 63 million euros, including tree removal, grower compensation, and lost production costs (Cambra et al. 2006). In North America about 264,000 trees in Canada and 190,000 trees in the United States (Pennsylvania) were destroyed in PPV control efforts. The cost of the PPV eradication program in Pennsylvania was approximately $\$ 40$ million over a 10 -year period 
(Cambra et al. 2006; Scorza et al. 2013). PPV is an expensive disease problem and is still a threat to the European and U.S. stone fruit industries.

In 1989, concerned with the potential threat to U.S. agriculture, scientists with the U.S. Department of Agriculture-Agricultural Research Service (USDA-ARS) initiated a research program to determine if PDR could be used to generate PPV-resistant plum (Prunus domestica). Transgenic plants engineered to express the PPV $\mathrm{CP}$ gene were generated. Some plant lines generated showed highly effective and durable resistance to PPV challenge. Transgenic VR plum plants have been tested for over 16 years in lab, greenhouse, and multilocation field testing (Scorza et al. 2013). In all tests, no tree was observed to become infected by aphid-transmitted PPV (Scorza et al. 2013). A 'Honeysweet' transgenic plum line was deregulated by the USDA, Food and Drug Administration, and Environmental Protection Agency in the United States in 2007, 2009, and 2011, respectively. As of 2016, the VR plum had not been grown commercially anywhere in the world. PPV is still widespread in Europe and a VR solution to this disease would save millions of euros and prevent destruction of millions of trees. As is the case with the other VR transgenic plants described in this section, the major impediment to widespread use of this technology is fear of consumer acceptance, NOT due to scientifically based concerns of safety and efficacy. Between 1999 and 2016, the only VR crop deregulated in the United States was PPV-resistant plum. If PPV-resistant plums were planted in the United States, if and when PPV again arrives in the United States, tens of millions of dollars and hundreds of thousands, if not millions, of trees could be saved.

Genetically engineered VR food crops deregulated outside of the United States. Outside of the United States, China and Brazil are the only other countries that have deregulated cultivation of VR transgenic plants. In 1998, transgenic tomato and pepper plants expressing the CMV CP gene were deregulated in China (James 2009; National Academies of Sciences and Medicine 2016). The extent to which they were cultivated in China is not clear. As mentioned above in 2006, a PRSV transgenic papaya expressing the PRSV CP gene was deregulated and has been extensively grown commercially in China (VIB 2014). Bean golden mosaic virus (genus Begomovirus)-resistant bean (Phaseolus vulgaris) was deregulated in Brazil in 2011 (Tollefson 2011). Estimates of dry bean production losses due to BGMV diseases in Brazil range from $90 \mathrm{~K}$ to $280 \mathrm{~K}$ tons (Faria et al. 2016), so widespread cultivation of this VR bean would have a significant impact on food production. However, as of 2017 the VR bean was not being commercially grown.
It is worth noting that the VR bean has effective resistance against a DNA virus; thus, genetically engineered approaches can be effective against both RNA and DNA plant-infecting viruses. Also, the resistance gene in the VR bean is not an application of CPMR, but rather uses an RNA-mediated resistance strategy using a portion of the BGMV rep protein gene sequence as a resistance gene. The examples of VR squash, potato, papaya, and plum, which were all transgenic for a virus $\mathrm{CP}$ gene, are also resistant not because they produce virus $\mathrm{CP}$, but due to an RNA-mediated resistance mechanism. Details of RNA-mediated resistance is briefly discussed in Part II of this review.

In the future, the next examples of engineered VR plants most likely to be deregulated and cultivated will probably be additional VR papaya cultivars. A number of research groups around the world have used PDR to generate potyvirus-resistant papaya lines (Fitch 2016) and have been testing VR plant lines for years. And PRSV continues to be a disease problem in many papaya-growing regions so there is a need for effective resistance. There is a diversity of papaya cultivars with different fruit types grown in different parts of the world, and a diversity of papaya-infecting potyvirus species and isolates worldwide. Thus, to be commercially useful, preferred local papaya cultivars must be engineered for resistance to the specific potyvirus species/isolates predominant in the local growing area (Bau et al. 2003; Kung et al. 2009) and different groups across the globe are doing just this to help protect local papaya production. If these are ever commercially grown, we would expect the benefits to growers, consumers, and the environment to be similar to the benefits observed in Hawaii when engineered VR papaya began being grown.

\section{PART II: BASIC RESEARCH ON PDR}

While great progress was being made in applying CPMR to realworld plant pathology problems, multiple groups were engaged in basic research trying to answer the question "How does CPMR work?" Although CPMR was tested with viruses from many different taxa, our understanding of the mechanisms behind CPMR has been most influenced by studying engineered virus resistance toward tobamoviruses or potyviruses. The results accumulated from over the last 30 years suggested that how CPMR works depends in part upon the virus system and on the particular transgenic plant being analyzed. In at least one example, transgene expressed CP does seem to be necessary for resistance. However, in most examples the mechanism of resistance does not involve a viral protein at all, but instead is an RNA-mediated phenomenon. We will first briefly review CPMR in TMV-resistant plants, a case where $\mathrm{CP}$ expression

\section{FIGURE 2}

Protection of engineered virus-resistant papaya from Papaya ringspot virus (PRSV) infection under field conditions in Hawaii, U.S. (2004). Foreground: field of susceptible (nontransgenic) papaya variety became infected by PRSV. No fruit was harvested

from plants in the nontransgenic papaya field.

Background: field of engineered virus-resistant papaya completely protected from PRSV infection. (Courtesy D. Gonsalves-Reproduced by permission)

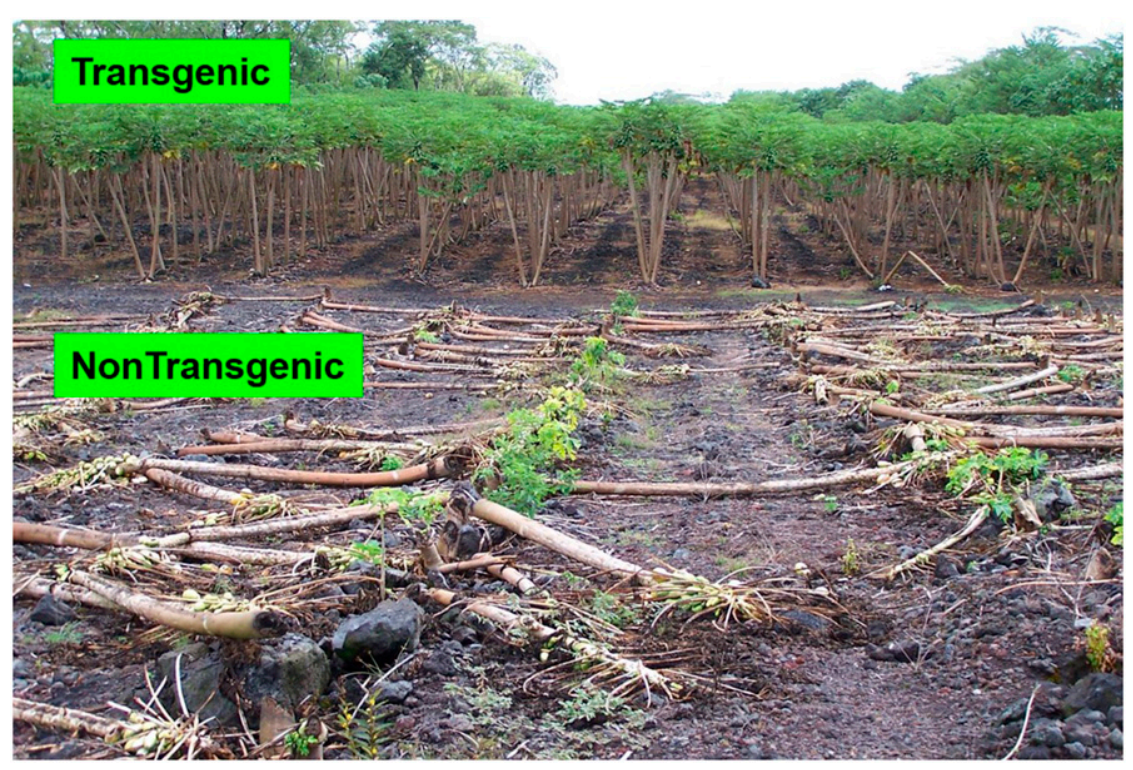


does appear to be important. Then we will discuss in more detail the unexpected discovery of RNA-mediated resistance and the virus immune phenotype often associated with this kind of resistance. We will also briefly discuss how insights from basic research on the phenomenon of RNA-mediated resistance have been used to improve the efficiency of engineered VR efforts and will likely impact future strategies. Figure 1 presents a timeline of some of the key milestones in basic research that have developed from the original demonstration of "CPMR."

The mechanism of CPMR in members of the genus Tobamovirus. The TMV resistance observed in transgenic plants expressing the TMV CP does appear to be a protein-mediated phenomenon. Perhaps the strongest evidence for this is a collection of experiments performed on transgenic plants that expressed mutated versions of the TMV CP. Transgenic plants expressing TMV CP variants that had stronger $\mathrm{CP}-\mathrm{CP}$ interactions and a tendency to aggregate showed a higher degree of resistance to TMV than did plants expressing (wild type) virus CP (Asurmendi et al. 2004, 2007; Bendahmane et al. 1997; Lu et al. 1998). Protoplast studies indicated that both virus movement protein expression and formation of virus replication complexes were reduced in transgenic protoplasts expressing wild type or mutant versions of TMV CP (Asurmendi et al. 2004; Bendahmane et al. 2007). This is an example in which ectopic expression of a virus protein reduced the expression and activity of other virus proteins, leading to a mild resistance phenotype. Reduction in movement protein expression and number of virus replication complexes is consistent with the delay in symptom appearance type of resistance observed in these $\mathrm{CP}$ expressing plants. One of the defining characteristics of the CP-mediated resistance toward TMV is that it is not immunity, but can be overcome with increasing inoculum levels, or by inoculation with purified TMV RNA (Osbourn et al. 1989; Register and Beachy 1988). This is in sharp contrast to examples of RNA-mediated resistance (discussed below) where plants can show immunity to high levels of either virus or viral RNA challenge.

Engineered virus resistance is often due to an RNAmediated resistance mechanism. Based on the resistance data reported for TMV CP expressing transgenic plants, it was initially hypothesized that when CPMR was applied to viruses of other taxa, $\mathrm{CP}$ expression levels would be positively correlated with degree of resistance. However, in many cases the degree of resistance was not positively correlated with transgene expressed protein levels. Such was the case for transgenic plants engineered to express CMV or PVY CPs (Cuozzo et al. 1988; Kaniewski et al. 1990; Lawson et al. 1990; Quemada et al. 1991). There were no satisfactory explanations for these observations when they were first reported. A breakthrough came when experiments were performed on a series of transgenic tobacco plants expressing different versions of the Tobacco etch virus (TEV, a member of the genus Potyvirus) CP gene. These seminal experiments clearly demonstrated that effective virus resistance could be obtained in the absence of any virus proteins and therefore must be RNA-mediated. These observations were the foundation for many new research questions and avenues.

First indication of RNA-mediated virus resistance. The first indications that genetically engineered virus resistance could be mediated by an RNA resistance appeared when it was reported that plants transgenic for a nontranslatable TEV CP gene sequence were immune to TEV infection (Lindbo and Dougherty 1992a, b). About $30 \%$ of the transgenic plant lines expressing a nontranslatable version of the TEV CP gene showed a TEV-immune phenotype (Lindbo et al. 1993). The resistance was characterized as immunity because TEV RNAs were not capable of replicating in individual cells from these resistant plants and resistance could not be overcome even by very high levels of TEV (virion or RNA) challenge. Interestingly, the TEV-immune plants tended to have high transgene transcription rates, but lower steady state transgene RNA levels than TEV-susceptible transgenic plants (Dougherty et al. 1994; Lindbo et al. 1993). Based on their observations, the authors hypothesized that in these TEV immune lines very high expression levels of the transgene had triggered a cellular sequencespecific RNA degradation response. This response resulted in post transcriptional gene silencing (PTGS) of both transgene transcripts and TEV genomic RNA, resulting in low steady state transgene RNA levels and also a TEV-immune phenotype. These observations generated intense interest both inside and outside of the plant biology community. A model for PTGS was first proposed in 1993 (Lindbo et al. 1993) and subsequently expanded upon. Figure 3 presents the remarkably insightful 1995 model for PTGS reproduced from Dougherty and Parks (1995). This early model predicted that small RNAs, generated from aberrant or over-expressed transgenes, were part of a cellular sequence-specific RNA targeting and degradation system. One remarkable prediction of the model was the estimation that the small RNAs responsible for the sequence-specific nature of this system would be 10 to $20 \mathrm{nts}$ in length. Over the next several years, experiments from both plant and animal biology contributed key observations to this phenomenon helping to fine tune the initial model.

Generation of a detailed understanding of the mechanism of PTGS. The model of PTGS proposed in 1995 triggered experimentation in plants and other eukaryotic systems as well. Similar examples of "gene silencing" were being reported in other biological systems at around this same time. As a result, research from many areas of biology contributed to refining the model and the development of a detailed understanding of the mechanism of PTGS. One key contribution was the discovery that dsRNAs were potent inducers of PTGS in plants and in nematodes (Montgomery and Fire 1998; Waterhouse et al. 1998). Then researchers studying PTGS in transgenic plants identified small (estimated to be about $25 \mathrm{nt}$ ) RNAs of complementary sequence to the silenced transgene (Hamilton and Baulcombe 1999). These were very similar in size to the small ( $\sim 10$ to $20 \mathrm{nt}$ ) RNAs Dougherty and Parks predicted in their 1995 model (Fig. 3). Biochemical experiments on Drosophila melanogaster soon demonstrated the presence of an RNA directed nuclease that directed PTGS (Hammond et al. 2000). The nuclease activity was part of a complex named the RNA induced silencing complex (RISC) and was found to contain small RNAs of $\sim 25 \mathrm{nt}$ (Hammond et al. 2000). Research in animal systems then identified a class of double-stranded (ds)RNA binding proteins called Dicers which processed dsRNAs into short duplexes of $\sim 22 \mathrm{nts}$ in length. Homologs of Dicer (called Dicer-like, DCL) proteins were also found in plants (Bernstein et al. 2001; Hammond et al. 2000). The small RNAs produced by DCL processing of dsRNAs were the source of small RNAs in the RISC. Finally, in 2004 it was shown that proteins of the Argonaute (AGO) class were the RNA cleaving "catalytic engine" of RISCs (Liu et al. 2004). After binding small RNAs an AGO protein used the bound RNA as a guide to specifically anneal to a complementary RNA target. After binding its target the AGO could then cleave a complementary target RNA sequence. This was the "second factor" proposed in Dougherty and Parks 1995 model (Fig. 3) to degrade targeted RNAs. Multiple copies of the genes and biochemical activities of DCL and AGO proteins were found in plants (review in Brodersen and Voinnet [2006]) and are now understood to function as key components of the cellular based sequence specific RNA degradation system first postulated to exist in 1993 (Lindbo et al. 1993). This small RNA gene regulation system was responsible for PTGS of transgenes, and for the VR phenotype in transgenic plants expressing nontranslatable versions of the TEV CP gene. This small RNA based gene regulation system is sometimes referred to as RNA-silencing or RNA interference (RNAi). In plants, cytoplasmic RNAs targeted by AGO protein-small RNA complexes can down regulate RNA targets by either degrading the RNA target or by suppressing the translation of the targeted RNA. Complete, or nearly complete complementarity between the small RNA and its target were necessary for AGOmediated regulation. For a more detailed review of the history of PTGS, RNA silencing of transgenes and virus resistance see Lindbo and Dougherty (2005). 
$R N A i$ and $C P M R$. Looking back today, our expanded knowledge of RNAi provides new perspective on old experimental results. For example, we now know that dsRNAs are potent triggers of RNAi. It is believed that in the $\sim 30 \%$ of transgenic lines expressing the nontranslatable TEV CP gene that showed a TEV immune phenotype (Lindbo et al. 1993), the transgene produced RNAs in those particular plant lines must have had a dsRNA nature. This structured RNA must have been processed by a DCL enzyme into small RNAs that programed AGO proteins in RISCs to target and degrade transgene transcripts as well as TEV genomic RNA. This is not unreasonable as multiple studies on transgenic plants have demonstrated that transgenes can often integrate into the host genome in complex structures such as multiple copies inverted toward each other, etc. (Jorgensen et al. 1996; Stam et al. 1998, 2000). Transcription of the DNA in these complex integration events would lead to RNAs which have dsRNA structure, leading to the production of small RNAs that would program RISCs.

Although RNAi was first recognized in transgenic plants expressing nontranslatable versions of a virus $\mathrm{CP}$ gene, it can also occur in plants transgenic for translatable versions of virus genes. All that is needed is for a (fortuitous) transgene integration event that will result in sufficient quantities of transgene RNA that has a dsRNA nature and is processed by DCLs into small RNAs that can program RISCs. After the mechanism of PTGS was defined, reanalysis of the examples of "CPMR" in the VR deregulated papaya and plum were determined to be due to an RNA-mediated resistance mechanism (Scorza et al. 2001; Tennant et al. 2001). Although a detailed mechanistic analysis of the deregulated VR squash (Tricoli et al. 1995) has not been reported, the extreme resistance to potyvirus infections in these plants suggests that the mechanism of resistance in these plants is probably mediated by RNA and not protein. In addition, at least some of the examples of "replicase-mediated resistance" have also been attributed to PTGS mechanism (Marano and Baulcombe 1998; Vazquez Rovere et al. 2001). Though there are likely some examples of replicase-mediated resistance that do have at least some component of resistance that is protein-mediated, perhaps in addition to an RNA-based response as well (Donson et al. 1993; Prins et al. 2008).

\section{IMPROVING THE PROCESS OF ENGINEERING VIRUS RESISTANCE}

Besides just providing intellectual satisfaction, the basic research on the mechanisms behind engineered virus resistance have led to more efficient strategies for engineering VR plants. The ideal process for generating genetically engineered virus resistance would result in $100 \%$ of the plant lines generated having complete immunity to the virus of interest. This, of course, was not the case with the first examples of engineered virus resistance. Toward that goal, researchers have tried to improve the process of engineering virus resistance in plants by incorporating insights gained from basic research.

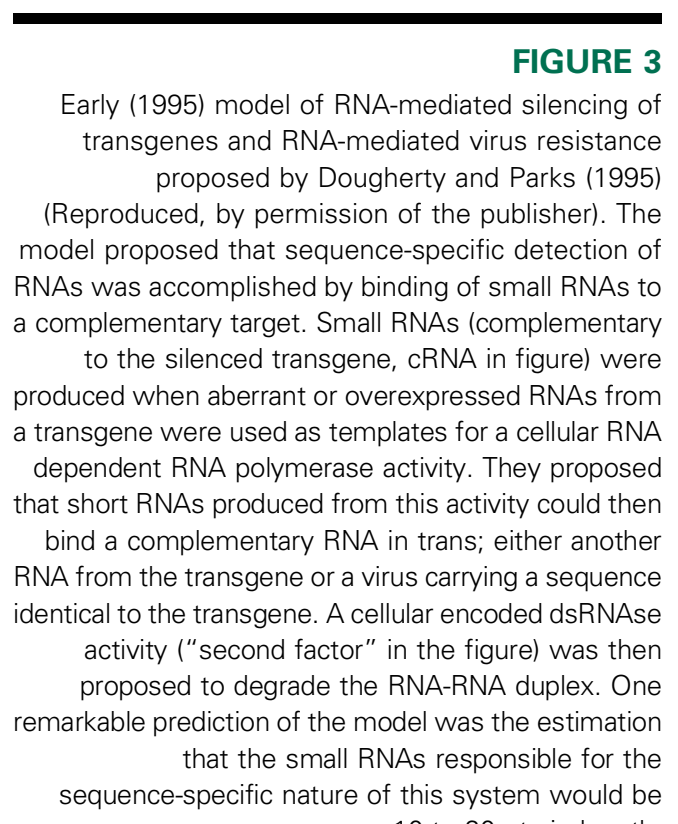

10 to $20 \mathrm{nts}$ in length.

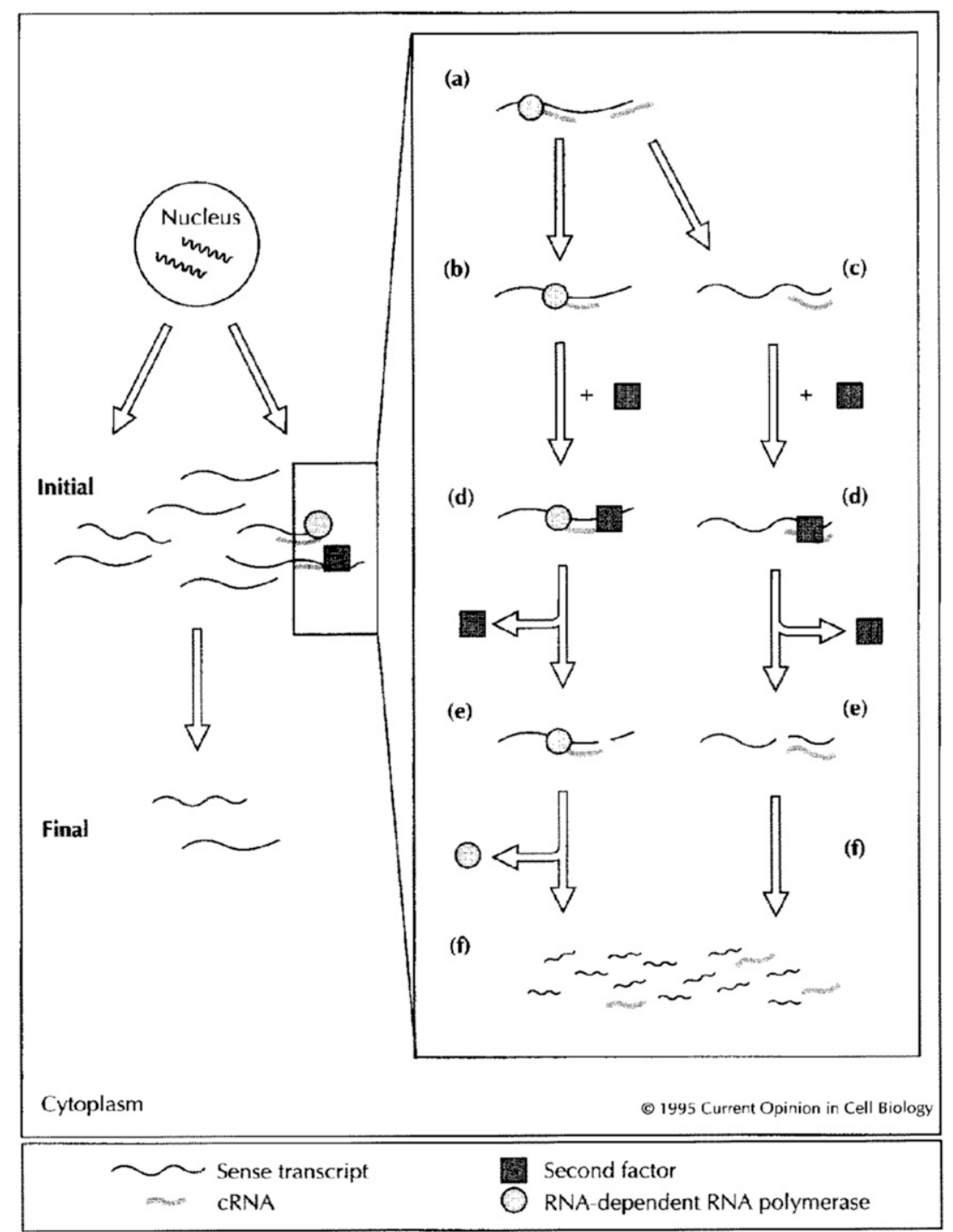


One of the first major improvements came when it was recognized that dsRNAs were potent triggers of PTGS. To take advantage of this researchers began constructing transgenes to contain virus gene sequences in inverted repeat (IR) orientation. Transcription of such a transgene generated an RNA which would efficiently base pair with itself to form a dsRNA in planta. In some experiments, nearly $90 \%$ of the transgenic plants lines transformed with transgenes of IRs of virus sequences showed RNA silencing and virus resistance (Waterhouse et al. 1998; Wesley et al. 2001). This IR strategy became an effective way to generate VR plants, using CP gene sequences, or sequences from other parts of the virus genome. For example, the BGMV-resistant bean deregulated in Brazil in 2011 (discussed above) expresses a transgene composed of an IR of a portion of the BGMV rep protein gene.

An added advantage of this strategy was that transcription of IRs of virus sequences as short as just a few hundred base pairs could trigger effective virus resistance. This made it easier to design transgenes that could confer resistance to multiple viruses. For example, using this IR approach it was possible to engineer plants resistant to four different tospoviruses by assembling $\sim 150$ bps of sequence from each of the four viruses and expressing the chimeric transgene as an IR (Bucher et al. 2006).

Still further refinements in engineering virus resistance using RNAi came after plant miRNA genes were identified (Llave et al. 2002). Two classes of small RNAs that naturally occur in plants are microRNAs (miRNAs) and short interfering RNAs (siRNAs). RNAs in these two classes overlap in size ( $\sim 21$ to $24 \mathrm{nt}$ ) and are distinguished according to their biogenesis in the cell (Tomari and Zamore 2005). miRNAs are $\sim 21$ to $22 \mathrm{nt}$ RNAs that are generated by DCL processing of premiRNAs. PremiRNAs are single-stranded (ss)RNAs transcribed from endogenous plant genes that have extensive self-complementary regions so that they fold back on themselves to create a structured RNA that is recognized by the dsRNA cleaving DCL. In contrast, siRNAs are $\sim 21$ to 24 nt RNAs generated by DCL processing of two separate RNA molecules that extensively base pair to each other to form a perfect or near perfect duplex. In either case, both miRNAs and siRNAs can become part of a RISC and be used in PTGS.

Multiple plant miRNA genes have been cloned and their processing by DCLs elucidated. Understanding the folding and processing of premiRNA has made it possible to engineer artificial miRNA (amiRNA) genes that will produce individual small RNAs of defined sequence. Effective virus resistance has been conferred by engineering plants to express just a single amiRNA gene designed to produce a single, virus-specific small RNA (Niu et al. 2006) that is perfectly complementary to its viral RNA target sequence. The amiRNA strategy required only about $21 \mathrm{nt}$ of virus genome sequence to construct a resistance gene-even less viral genome sequence than the hairpin RNA strategy described above. In order to generate plants resistant to multiple viruses, researchers have joined multiple amiRNA genes together to create transgene cassettes that conferred resistance to both a potyvirus and a tymovirus (Niu et al. 2006). Since the initial demonstration that amiRNAs can be used as virus resistance genes, this strategy has also been successfully applied to viruses of the cucumo, potex, begomovirus, and tospovirus taxa (Ai et al. 2011; Ali et al. 2013; Duan et al. 2008; Mitter et al. 2016; Qu et al. 2007; Zhang et al. 2011). Although effective in lab studies, no engineered VR plants using amiRNAs for the resistance mechanism have been approved for commercial use as of 2017.

\section{SUMMARY AND FUTURE OUTLOOK}

Over time we have observed an evolution of strategies for engineering virus resistance in plants. The evolution has been toward producing fewer and fewer virus-specific biomolecules in plants and yet recovering higher and higher percentages of VR plant lines. Initially, large virus sequences over several hundred to nearly $1 \mathrm{~kb}$ of translatable sequence were used. These transgenes were designed to produce both viral RNA and proteins in plants. Next, nontranslatable virus sequences were used, that only expressed RNA, not protein. Then, purposeful production of dsRNAs through expression of IRs let synthetic virus resistance genes be composed of only a few hundred base pairs of sequence. Next came production of amiRNA genes, which only contained $\sim 21 \mathrm{nts}$ of virus sequence embedded into a plant miRNA gene. Each change has been a more specific, targeted design, requiring the addition of less and less "foreign" sequences to plants for each virus resistance generated.

So what will be the next steps and future directions of engineered virus resistance strategies? One possibility is that genome editing using CRISPR/Cas (Bortesi and Fischer 2015; Noman et al. 2016) may be used to alter the specificity of existing plant miRNA genes in place so that they produce a miRNA that targets a virus of interest. Such a gene editing approach could require perhaps changing only 20 or so nucleotides of the entire plant genome to generate a new virus resistance gene. If effective virus resistance could be obtained with this genome editing strategy, this would represent a new milestone in the evolution of engineered virus resistance through RNA-mediated silencing mechanisms.

Final thoughts on engineering virus resistance in plants. Viruses continue to be significant plant pathogens despite our efforts to control the diseases they cause. Viruses continue to evolve, breaking down resistance from the naturally occurring resistance genes (Crescenzi et al. 2013; Lopez et al. 2011) we deploy. Viruses also continue to move into new environments (aided by the global nature of modern agriculture and human travel) and find new hosts often with devastating consequences (Li et al. 2013; Salem et al. 2016). As a result, the need for environmentally friendly and effective virus control strategies is greater than ever. Plant breeding programs around the world are struggling to identify effective resistance genes toward evolving and emerging viral pathogens. A primary goal is to develop highly productive VR crop varieties. But in many cases effective resistance genes have not yet been found.

Regardless of the future strategies, the ability to generate genetically controlled virus resistance is an important one for agriculture, particularly with viruses and other plant pathogens that drastically affect crop plants grown for food. This is a need for agriculture worldwide. For over two decades engineered VR plants have been grown and delivered benefits to farmers, consumers, and the environment. We have highlighted in this review the benefits (or potential benefits) of growing engineered VR crops which have been approved for commercial use. Engineered VR plants have an excellent record of safety and performance. There are additional crops where application of engineered virus resistance would have tremendous benefits. Current plant virus diseases such as cassava mosaic and maize lethal necrosis threaten food security in regions of the world where the population relies on subsistence farming (Alabi et al. 2011; Mahuku et al. 2015). Resistance to the viruses causing these diseases could be rapidly developed and thus provide food security, help fight poverty, yield environmental benefits, and promote public health. Regardless of the exact design and composition of future genetically engineered virus resistance genes, we anticipate further application of this technology. We can and should use this technology more often. It has been proven to be safe, effective, and environmentally friendly. It is a strategy for improving reliable production of food that requires zero chemical inputs from the farmer and delivers many social and environmental benefits.

\section{ACKNOWLEDGMENTS}

We thank D. Gonsalves for graciously supplying the photograph used here for Figure 2. 


\section{LITERATURE CITED}

Abel, P. P., Nelson, R. S., De, B., Hoffmann, N., Rogers, S. G., Fraley, R. T., and Beachy, R. N. 1986. Delay of disease development in transgenic plants that express the Tobacco mosaic virus coat protein gene. Science 232: 738-743.

Ai, T., Zhang, L., Gao, Z., Zhu, C. X., and Guo, X. 2011. Highly efficient virus resistance mediated by artificial microRNAs that target the suppressor of PVX and PVY in plants. Plant Biol. 13:304-316.

Alabi, O. J., Kumar, P. L., and Naidu, R. A. 2011. Cassava mosaic disease: A curse to food security in sub-Saharan Africa. APSnet Features. doi:10.1094/ APSnetFeature-2011-0701

Ali, I., Amin, I., Briddon, R. W., and Mansoor, S. 2013. Artificial microRNAmediated resistance against the monopartite begomovirus Cotton leaf curl Burewala virus. Virol. J. 10:231.

Anderson, J. M., Palukaitis, P., and Zaitlin, M. 1992. A defective replicase gene induces resistance to Cucumber mosaic virus in transgenic tobacco plants. Proc. Natl. Acad. Sci. USA 89:8759-8763.

Anderson, P. K., Cunningham, A. A., Patel, N. G., Morales, F. J., Epstein, P. R., and Daszak, P. 2004. Emerging infectious diseases of plants: Pathogen pollution, climate change and agrotechnology drivers. Trends Ecol. Evol. 19:535-544

Arce-Ochoa, J. P., Dainello, F., Pike, L. M., and Drews, D. 1995. Transgenic summer squash hybrids and their parental hybrid line. HortScience 30: 492-493.

Asurmendi, S., Berg, R. H., Koo, J. C., and Beachy, R. N. 2004. Coat protein regulates formation of replication complexes during Tobacco mosaic virus infection. Proc. Natl. Acad. Sci. USA 101:1415-1420.

Asurmendi, S., Berg, R. H., Smith, T. J., Bendahmane, M., and Beachy, R. N. 2007. Aggregation of TMV CP plays a role in CP functions and in coatprotein-mediated resistance. Virology 366:98-106.

Bau, H.-J., Cheng, Y.-H., Yu, T.-A., Yang, J.-S., and Yeh, S. D. 2003. Broadspectrum resistance to different geographic strains of Papaya ringspot virus in coat protein gene transgenic papaya. Phytopathology 93:112-120.

Beachy, R. N. 1999. Coat-protein-mediated resistance to Tobacco mosaic virus: Discovery mechanisms and exploitation. Philos. Trans. R. Soc. Lond. B Biol. Sci. 354:659-664.

Beachy, R. N., Loesch-Fries, S., and Tumer, N. 1990. Coat protein-mediated resistance against virus infection. Annu. Rev. Phytopathol. 28:451-474.

Bendahmane, M., Chen, I., Asurmendi, S., Bazzini, A. A., Szecsi, J., and Beachy, R. N. 2007. Coat protein-mediated resistance to TMV infection of Nicotiana tabacum involves multiple modes of interference by coat protein. Virology 366:107-116.

Bendahmane, M., Fitchen, J. H., Zhang, G., and Beachy, R. N. 1997. Studies of coat protein-mediated resistance to tobacco mosaic tobamovirus: Correlation between assembly of mutant coat proteins and resistance. J. Virol. 71:7942-7950.

Bergua, M., Kang, S. H., and Folimonova, S. Y. 2016. Understanding superinfection exclusion by complex populations of Citrus tristeza virus. Virology 499:331-339.

Bernstein, E., Caudy, A. A., Hammond, S. M., and Hannon, G. J. 2001. Role for a bidentate ribonuclease in the initiation step of RNA interference. Nature 409:363-366

Bortesi, L., and Fischer, R. 2015. The CRISPR/Cas9 system for plant genome editing and beyond. Biotechnol. Adv. 33:41-52.

Brodersen, P., and Voinnet, O. 2006. The diversity of RNA silencing pathways in plants. Trends Genet. 22:268-280.

Bucher, E., Lohuis, D., van Poppel, P. M., Geerts-Dimitriadou, C., Goldbach, R., and Prins, M. 2006. Multiple virus resistance at a high frequency using a single transgene construct. J. Gen. Virol. 87:3697-3701.

Cambra, M., Capote, N., Myrta, A., and Llacer, G. 2006. Plum pox virus and the estimated costs associated with sharka disease. EPPO Bull. 36: 202-204.

Clark, W. G., Register, J. C., 3rd, Nejidat, A., Eichholtz, D. A., Sanders, P. R., Fraley, R. T., and Beachy, R. N. 1990. Tissue-specific expression of the TMV coat protein in transgenic tobacco plants affects the level of coat protein-mediated virus protection. Virology 179:640-647.

Crescenzi, A., Viggiano, A., and Fanigliulo, A. 2013. Resistance breaking Tomato spotted wilt virus isolates on resistant pepper varieties in Italy. Commun. Agric. Appl. Biol. Sci. 78:609-612.

Cuozzo, M., O’Connell, K. M., Kaniewski, W., Fang, R., Chua, N. H., and Tumer, N. 1988. Viral protection in transgenic tobacco plants expressing the Cucumber mosaic virus coat protein or its antisense RNA. Nat. Biotechnol. 6:549-557.

Donson, J., Kearney, C., Turpen, T., Khan, I., Kurath, G., Turpen, A., Jones, G., Dawson, W., and Lewandowski, D. 1993. Broad resistance to tobamoviruses is mediated by a modified Tobacco mosaic virus replicase transgene. Mol. Plant-Microbe Interact. 6:635-642.
Dougherty, W. G., Lindbo, J. A., Smith, H. A., Parks, T. D., Swaney, S., and Proebsting, W. M. 1994. RNA-mediated virus resistance in transgenic plants: Exploitation of a cellular pathway possibly involved in RNA degradation. Mol. Plant-Microbe Interact. 7:544-552.

Dougherty, W. G., and Parks, T. D. 1995. Transgenes and gene suppression: Telling us something new? Curr. Opin. Cell Biol. 7:399-405.

Duan, C. G., Wang, C. H., Fang, R. X., and Guo, H. S. 2008. Artificial MicroRNAs highly accessible to targets confer efficient virus resistance in plants. J. Virol. 82:11084-11095.

Faria, J., Aragao, F., Souza, T., Quintela, E., Kitajima, E., and Ribeiro, S. 2016. Golden mosaic of common beans in Brazil: Management with a transgenic approach. APSnet Features.

Fitch, M. M., Manshardt, R. M., Gonsalves, D., and Slightom, J. L. 1993. Transgenic papaya plants from Agrobacterium-mediated transformation of somatic embryos. Plant Cell Rep. 12:245-249.

Fitch, M. M. M. 2016. Update on gene transfer biotechnology of papaya. Acta Hortic. 1111:7-18

Fitch, M. M. M., Manshardt, R. M., Gonsalves, D., Slightom, J., and Sanford, J. C. 1992. Virus resistant papaya plants derived from tissues bombarded with the coat protein gene of Papaya ringspot virus. Nat. Biotechnol. 10:1466-1472.

Folimonova, S. Y. 2013. Developing an understanding of cross-protection by Citrus tristeza virus. Front. Microbiol. 4:76.

Fuchs, M., and Gonsalves, D. 2007. Safety of virus-resistant transgenic plants two decades after their introduction: Lessons from realistic field risk assessment studies. Annu. Rev. Phytopathol. 45:173-202.

Fuchs, M., Tricoli, D. M., Carney, K. J., Schesser, M., McFerson, J. R., and Gonsalves, D. 1998. Comparative virus resistance and fruit yield of transgenic squash with single and multiple coat protein genes. Plant Dis. 82: 1350-1356.

Garcia, J. A., Glasa, M., Cambra, M., and Candresse, T. 2014. Plum pox virus and sharka: A model potyvirus and a major disease. Mol. Plant Pathol. 15:226-241.

Golemboski, D. B., Lomonossoff, G. P., and Zaitlin, M. 1990. Plants transformed with a Tobacco mosaic virus nonstructural gene sequence are resistant to the virus. Proc. Natl. Acad. Sci. USA 87:6311-6315.

Gonsalves, D. 2015. The wayward Hawaiian boy returns home. Annu. Rev. Phytopathol. 53:1-17

Gonsalves, D., Gonsalves, C., Ferriera, S., Pitz, K., Fitch, M. M., Manshardt, R. M., and Slightom, J. 2004. Transgenic virus resistant papaya: From hope to reality for controlling Papaya ringspot virus in Hawaii. APSnet Features. American Phytopathological Society, St. Paul, MN.

Hamilton, A. J., and Baulcombe, D. C. 1999. A species of small antisense RNA in posttranscriptional gene silencing in plants. Science 286:950-952.

Hammond, S. M., Bernstein, E., Beach, D., and Hannon, G. J. 2000. An RNAdirected nuclease mediates post-transcriptional gene silencing in Drosophila cells. Nature 404:293-296

Hull, R. 2014. Matthews' Plant Virology. Academic Press.

James, C. 2009. Global status of commercialized biotech. GM Crops 2008. ISAAA, Ithaca, NY.

Johnson, S. R., Strom, S., and Grillo, K. 2007. Quantification of the impacts on US agriculture of biotechnology-derived crops planted in 2006. National Center for Food and Agriculture Policy. http://www.ncfap.org

Jorgensen, R. A., Cluster, P. D., English, J., Que, Q., and Napoli, C. A. 1996. Chalcone synthase cosuppression phenotypes in petunia flowers: Comparison of sense vs. antisense constructs and single-copy vs. complex T-DNA sequences. Plant Mol. Biol. 31:957-973.

Kaniewski, W., Lawson, C., Sammons, B., Haley, L., Hart, J., Delannay, X., and Tumer, N. 1990. Field resistance of transgenic Russet Burbank potato to effects of infection by Potato virus $X$ and Potato virus $Y$. Nat. Biotechnol. $8: 750-754$

Kaniewski, W. K., and Thomas, P. E. 2004. The potato story. AgBioForum 7:41-46.

Kawchuk, L. M., Martin, R. R., and McPherson, J. 1990. Resistance in transgenic potato expressing the Potato leafroll virus coat protein gene. Mol. Plant-Microbe Interact. 3:301-307.

Kumari, S., Trivedi, M., and Mishra, M. 2015. PRSV resistance in papaya (Carica papaya L.) through genetic engineering: A review. J. Appl. Hortic. 17:243-248.

Kung, Y. J., Huey-Jiunn, B., Wu, Y.-L., Huang, C. H., Chen, T. M., and Yeh, S. D. 2009. Generation of transgenic papaya with double resistance to Papaya ringspot virus and Papaya leaf-distortion mosaic virus. Phytopathology 99:1312-1320.

Kyle, M. 1993. Resistance to Viral Diseases of Vegetables. Timber Press, Portland, OR

Lawson, C., Kaniewski, W., Haley, L., Rozman, R., Newell, C., Sanders, P., and Tumer, N. E. 1990. Engineering resistance to mixed virus infection in a commercial potato cultivar: Resistance to Potato virus $X$ and Potato virus $Y$ in transgenic Russet Burbank. Biotechnology (N.Y.) 8:127-134. 
Li, R., Gao, S., Fei, Z., and Ling, K. S. 2013. Complete genome sequence of a new tobamovirus naturally infecting tomatoes in Mexico. Genome Announc. 1:e00794-13.

Lindbo, J. A., and Dougherty, W. G. 1992a. Pathogen-derived resistance to a potyvirus: Immune and resistant phenotypes in transgenic tobacco expressing altered forms of a potyvirus coat protein nucleotide sequence. Mol. Plant-Microbe Interact. 5:144-153.

Lindbo, J. A., and Dougherty, W. G. 1992b. Untranslatable transcripts of the Tobacco etch virus coat protein gene sequence can interfere with Tobacco etch virus replication in transgenic plants and protoplasts. Virology 189:725-733.

Lindbo, J. A., and Dougherty, W. G. 2005. Plant pathology and RNAi: A brief history. Annu. Rev. Phytopathol. 43:191-204.

Lindbo, J. A., Silva-Rosales, L., Proebsting, W. M., and Dougherty, W. G. 1993. Induction of a highly specific antiviral state in transgenic plants: Implications for regulation of gene expression and virus resistance. Plant Cell 5:1749-1759.

Liu, J., Carmell, M. A., Rivas, F. V., Marsden, C. G., Thomson, J. M., Song, J. J., Hammond, S. M., Joshua-Tor, L., and Hannon, G. J. 2004. Argonaute2 is the catalytic engine of mammalian RNAi. Science 305:1437-1441.

Lius, S., Manshardt, R. M., Fitch, M. M. M., Slightom, J. L., Sanford, J. C., and Gonsalves, D. 1997. Pathogen-derived resistance provides papaya with effective protection against Papaya ringspot virus. Mol. Breed. 3:161-168.

Llave, C., Kasschau, K. D., Rector, M. A., and Carrington, J. C. 2002. Endogenous and silencing-associated small RNAs in plants. Plant Cell 14: 1605-1619.

Lopez, C., Aramburu, J., Galipienso, L., Soler, S., Nuez, F., and Rubio, L. 2011. Evolutionary analysis of tomato $\mathrm{Sw}-5$ resistance-breaking isolates of Tomato spotted wilt virus. J. Gen. Virol. 92:210-215.

Lu, B., Stubbs, G., and Culver, J. N. 1998. Coat protein interactions involved in tobacco mosaic tobamovirus cross-protection. Virology 248:188-198.

Mahuku, G., Lockhart, B. E., Wanjala, B., Jones, M. W., Kimunye, J. N., Stewart, L. R., Cassone, B. J., Sevgan, S., Nyasani, J. O., Kusia, E., Kumar, P. L., Niblett, C. L., Kiggundu, A., Asea, G., Pappu, H. R., Wangai, A., Prasanna, B. M., and Redinbaugh, M. G. 2015. Maize lethal necrosis (MLN), an emerging threat to maize-based food security in Sub-Saharan Africa. Phytopathology 105:956-965.

Malmstrom, C. M., and Alexander, H. M. 2016. Effects of crop viruses on wild plants. Curr. Opin. Virol. 19:30-36.

Marano, M. R., and Baulcombe, D. 1998. Pathogen-derived resistance targeted against the negative-strand RNA of Tobacco mosaic virus: RNA strandspecific gene silencing? Plant J. 13:537-546.

McKinney, H. H. 1929. Mosaic disease in the Canary Islands, West Africa, and Gibralter. J. Agric. Res. 39:557-578.

Mitter, N., Zhai, Y., Bai, A. X., Chua, K., Eid, S., Constantin, M., Mitchell, R., and Pappu, H. R. 2016. Evaluation and identification of candidate genes for artificial microRNA-mediated resistance to Tomato spotted wilt virus. Virus Res. 211:151-158.

Montgomery, M. K., and Fire, A. 1998. Double-stranded RNA as a mediator in sequence-specific genetic silencing and co-suppression. Trends Genet. 14:255-258.

Muthukumar, V., Melcher, U., Pierce, M., Wiley, G. B., Roe, B. A., Palmer, M. W., Thapa, V., Ali, A., and Ding, T. 2009. Non-cultivated plants of the Tallgrass Prairie Preserve of northeastern Oklahoma frequently contain virus-like sequences in particulate fractions. Virus Res. 141:169-173.

National Academies of Sciences and Medicine. 2016. Genetically Engineered Crops: Experiences and Prospects. The National Academies Press, Washington, DC

Nejidat, A., and Beachy, R. N. 1989. Decreased levels of TMV coat protein in transgenic tobacco plants at elevated temperatures reduce resistance to TMV infection. Virology 173:531-538.

Nelson, R. S., Abel, P. P., and Beachy, R. N. 1987. Lesions and virus accumulation in inoculated transgenic tobacco plants expressing the coat protein gene of Tobacco mosaic virus. Virology 158:126-132.

Niu, Q. W., Lin, S. S., Reyes, J. L., Chen, K. C., Wu, H. W., Yeh, S. D., and Chua, N. H. 2006. Expression of artificial microRNAs in transgenic Arabidopsis thaliana confers virus resistance. Nat. Biotechnol. 24:1420-1428.

Noman, A., Aqeel, M., and He, S. 2016. CRISPR-Cas9: Tool for qualitative and quantitative plant genome editing. Front. Plant Sci. 7:1740.

Osbourn, J. K., Watts, J. W., Beachy, R. N., and Wilson, T. M. 1989. Evidence that nucleocapsid disassembly and a later step in virus replication are inhibited in transgenic tobacco protoplasts expressing TMV coat protein. Virology 172:370-373.

Prins, M., Laimer, M., Noris, E., Schubert, J., Wassenegger, M., and Tepfer, M. 2008. Strategies for antiviral resistance in transgenic plants. Mol. Plant Pathol. 9:73-83.
Qu, J., Ye, J., and Fang, R. 2007. Artificial microRNA-mediated virus resistance in plants. J. Virol. 81:6690-6699.

Quemada, H. D., Gonsalves, D., and Slightom, J. 1991. Expression of coat protein gene from Cucumber mosaic virus strain $\mathrm{C}$ in tobacco: Protection against infections by CMV strains transmitted mechanically or by aphids. Phytopathology 81:794-802.

Register, J. C., 3rd, and Beachy, R. N. 1988. Resistance to TMV in transgenic plants results from interference with an early event in infection. Virology 166:524-532.

Salem, N., Mansour, A., Ciuffo, M., Falk, B. W., and Turina, M. 2016. A new tobamovirus infecting tomato crops in Jordan. Arch. Virol. 161:503-506.

Sanford, J. C., and Johnston, S. A. 1985. The concept of parasite-derived resistance-deriving resistance genes from the parasite's own genome. J. Theor. Biol. 113:395-405.

Scorza, R., Callahan, A., Dardick, C., Ravelonandro, M., Polak, J., Malinowski, T., Zagrai, I., Cambra, M., and Kamenova, I. 2013. Genetic engineering of Plum pox virus resistance: 'HoneySweet' plum-from concept to product. Plant Cell Tissue Organ Cult. (PCTOC) 115:1-12.

Scorza, R., Callahan, A., Laurene, L., Damsteegt, V., Webb, K., and Ravelonandro, M. 2001. Post-transcriptional gene silencing in Plum pox virus resistant transgenic European plum containing the plum pox potyvirus coat protein gene. Transgenic Res. 10:201-209.

Stam, M., de Bruin, R., van Blokland, R., van der Hoorn, R. A., Mol, J. N., and Kooter, J. M. 2000. Distinct features of post-transcriptional gene silencing by antisense transgenes in single copy and inverted T-DNA repeat loci. Plant J. 21:27-42.

Stam, M., Viterbo, A., Mol, J. N., and Kooter, J. M. 1998. Position-dependent methylation and transcriptional silencing of transgenes in inverted T-DNA repeats: Implications for posttranscriptional silencing of homologous host genes in plants. Mol. Cell. Biol. 18:6165-6177.

Tennant, P., Fermin, G., Fitch, M. M., Manshardt, R. M., Slightom, J., and Gonsalves, D. 2001. Papaya ringspot virus resistance of transgenic rainbow and SunUp is affected by gene dosage, plant development, and coat protein homology. Eur. J. Plant Pathol. 107:645-653.

Tollefson, J. 2011. Brazil cooks up transgenic bean. Nature 478:168.

Tomari, Y., and Zamore, P. D. 2005. Perspective: Machines for RNAi. Genes Dev. 19:517-529.

Tricoli, D. M., Carney, K. J., Russell, P. F., McMaster, J. R., Groff, D. W., Hadden, K. C., Himmel, P. T., Hubbard, J. P., Boeshore, M. L., and Quemada, H. D. 1995. Single or multiple virus coat protein gene constructs for resistance to Cucumber mosaic virus, Watermelon mosaic virus 2, and Zucchini yellow mosaic virus. Nat. Biotechnol. 13:1458-1465.

Tripathi, S., Suzuki, J., and Gonsalves, D. 2007. Development of genetically engineered resistant papaya for Papaya ringspot virus in a timely manner: A comprehensive and successful approach. Methods Mol. Biol. 354:197-240.

USDA-APHIS. 2016. Petitions for Determination of Nonregulated Status. USDAAPHIS Petitions for Determination of Nonregulated Status. https://www.aphis. usda.gov/aphis/ourfocus/biotechnology/permits-notifications-petitions/petitions/ petition-status

Vazquez Rovere, C., Asurmendi, S., and Hopp, H. E. 2001. Transgenic resistance in potato plants expressing Potato leaf roll virus (PLRV) replicase gene sequences is RNA-mediated and suggests the involvement of posttranscriptional gene silencing. Arch. Virol. 146:1337-1353.

VIB. 2014. Virus resistant papaya in Hawaii: The local papaya industry's life raft. In: Fact Series: Virus Resistant Papaya in Hawaii. VIB, Gent, Belgium.

Waterhouse, P. M., Graham, M. W., and Wang, M. B. 1998. Virus resistance and gene silencing in plants can be induced by simultaneous expression of sense and antisense RNA. Proc. Natl. Acad. Sci. USA 95:13959-13964.

Wesley, S. V., Helliwell, C. A., Smith, N. A., Wang, M. B., Rouse, D. T., Liu, Q., Gooding, P. S., Singh, S. P., Abbott, D., Stoutjesdijk, P. A., Robinson, S. P., Gleave, A. P., Green, A. G., and Waterhouse, P. M. 2001. Construct design for efficient, effective and high-throughput gene silencing in plants. Plant J. 27:581-590.

Whitfield, A. E., Falk, B. W., and Rotenberg, D. 2015. Insect vector-mediated transmission of plant viruses. Virology 479-480:278-289.

Whitham, S. A., and Hajimorad, M. R. 2016. Plant Genetic Resistance to Viruses. Springer, AG Switzerland. doi:10.1007/978-3-319-32919-2_4

Wisniewski, L. A., Powell, P. A., Nelson, R. S., and Beachy, R. N. 1990. Local and systemic spread of Tobacco mosaic virus in transgenic tobacco. Plant Cell 2:559-567.

Zhang, X., Li, H., Zhang, J., Zhang, C., Gong, P., Ziaf, K., Xiao, F., and Ye, Z. 2011. Expression of artificial microRNAs in tomato confers efficient and stable virus resistance in a cell-autonomous manner. Transgenic Res. 20:569-581.

Ziebell, H., and Carr, J. P. 2010. Cross-protection: A century of mystery. Adv. Virus Res. 76:211-264. 